\title{
Murine leukemia virus RNA dimerization is coupled to transcription and splicing processes
}

Stéphan Maurel, Marylène Mougel

\begin{abstract}
Most of the cell biological aspects of retroviral genome dimerization remain unknown. Murine leukemia virus (MLV) constitutes a useful model to study when and where dimerization occurs within the cell. For instance, MLV produces a subgenomic RNA (called SD') that is co-packaged with the genomic RNA predominantly as FLSD' heterodimers. This SD' RNA is generated by splicing of the genomic RNA and also by direct transcription of a spliceassociated retroelement of MLV (SDARE). We took advantage of these two SD' origins to study the effects of transcription and splicing events on RNA dimerization. Using genetic approaches coupled to capture of RNA heterodimer in virions, we determined heterodimerization frequencies in different cellular contexts. Several cell lines were stably established in which SD' RNA was produced by either splicing or transcription from SDARE. Moreover, SDARE was integrated into the host chromosome either concomitantly or sequentially with the genomic provirus. Our results showed that transcribed genomic and SD' RNAs preferentially formed heterodimers when their respective proviruses were integrated together. In contrast, heterodimerization was strongly affected when the two proviruses were integrated independently. Finally, dimerization was enhanced when the transcription sites were expected to be physically close. For the first time, we report that splicing and RNA dimerization appear to be coupled. Indeed, when the RNAs underwent splicing, the FLSD' dimerization reached a frequency similar to co-transcriptional heterodimerization. Altogether, our results indicate that randomness of heterodimerization increases when RNAs are co-expressed during either transcription or splicing. Our results strongly support the notion that dimerization occurs in the nucleus, at or near the transcription and splicing sites, at areas of high viral RNA concentration.
\end{abstract}

\section{Findings}

The dimeric nature of the genome is strongly conserved among Retroviridae, underlying the importance of RNA dimerization for virus replication. Packaging of two genome copies increases the probability of recombination events by template switching upon the reverse transcription, thus promoting genetic diversity [1]. Dimerization may play an additional role in the sorting of the viral full-length RNA (FL RNA) between different fates, including splicing, translation, and packaging [2]. RNA structural switches induced by dimerization might be responsible for such RNA versatility [3-8]. Dimerization and packaging of MLV unspliced RNAs are well documented with identification of the RNA cis-element (Psi) and its interaction with the trans-acting Gag factor [6,9-18]. Dimerization appears to be a prerequisite for

\footnotetext{
* Correspondence: mmougel@univ-montp1.fr
Université Montpellier 1, Centre d'études d'agents Pathogènes et

* Correspondence: mmougel@univ-montp1.fr Biotechnologies pour la Santé (CPBS), CNRS, UMR 5236, 4 Bd Henri IV, 34965 Montpellier, France
}

(c) 2010 Maurel and Mougel; licensee BioMed Central Ltd. This is an Open Access article distributed under the terms of the Creative Commons Attribution License (http://creativecommons.org/licenses/by/2.0), which permits unrestricted use, distribution, and reproduction in any medium, provided the original work is properly cited.

genomic RNA packaging [19] and could participate in the selection of the genome among a multitude of cellular and viral mRNAs. However, where and when RNA dimerization occurs in cell have long remained unresolved [19-21], and constitute the aims of the present study.

Presumably, dimerization occurs in the cell prior to RNA packaging as supported by recent microscopy studies at single-RNA-detection sensitivity [22,23]. Moreover, the co-localization of Gag and FL RNA in the nucleus suggests that Gag might bind the FL RNA inside the nucleus [24-26]. Such a connection between Gag nuclear trafficking and genome packaging provides an attractive model for how retroviruses first recruit their genomes. The consequence of the nuclear RNA life on RNA packaging and presumably on RNA dimerization is also supported by genetic approaches [27-30]. For instance, transcription of two MLV RNAs expressed from a single locus favored their co-packaging while transcription from distant loci did not. Here, we 
undertook the same genetic approaches coupled with virion RNA capture assays (RCA) to determine whether transcription and splicing steps could impact RNA dimerization efficiency. We took advantage of a unique characteristic of MLV to produce a splice-associated retroelement (SDARE) [31].

In addition to the env mRNA, MLV produces an alternatively spliced 4.4-Kb RNA, called SD' RNA (Figure 1A). This alternative splicing recruits a splice donor site, SD', which is conserved among types $C$ and D mammalian oncoretroviruses. Intact $\mathrm{SD}^{\prime}$ is required for optimal virus replication and pathogenesis [32-35]. During the MLV life cycle, the SD' RNA shares all the characteristics of the FL RNA, since it goes through encapsidation, reverse transcription and integration steps. It acts as a defective retroelement (SDARE) that enables SD' RNA production via direct transcription by the cellular machinery, without the need for a splicing step [31]. Therefore, the SD' RNA can be generated via two different pathways, either by splicing of the FL RNA (splSD') or by direct transcription of SDARE (trSD').

The FL and SD' RNAs harbor the same Psi sequence responsible for their co-packaging. In vitro, the two RNAs harbored similar dimerization abilities and formed Psi-dependent heterodimers (FLSD') [36]. Analysis of virion content by RCA revealed that the SD' RNA was co-packaged with the FL RNA predominantly as heterodimeric forms [36]. This preferential dimerization of SD' RNA with FL RNA may influence recombination events since their association could restrict the interaction of FL RNA with other defective endogenous retroviruses or virus-like elements, and may have consequences in

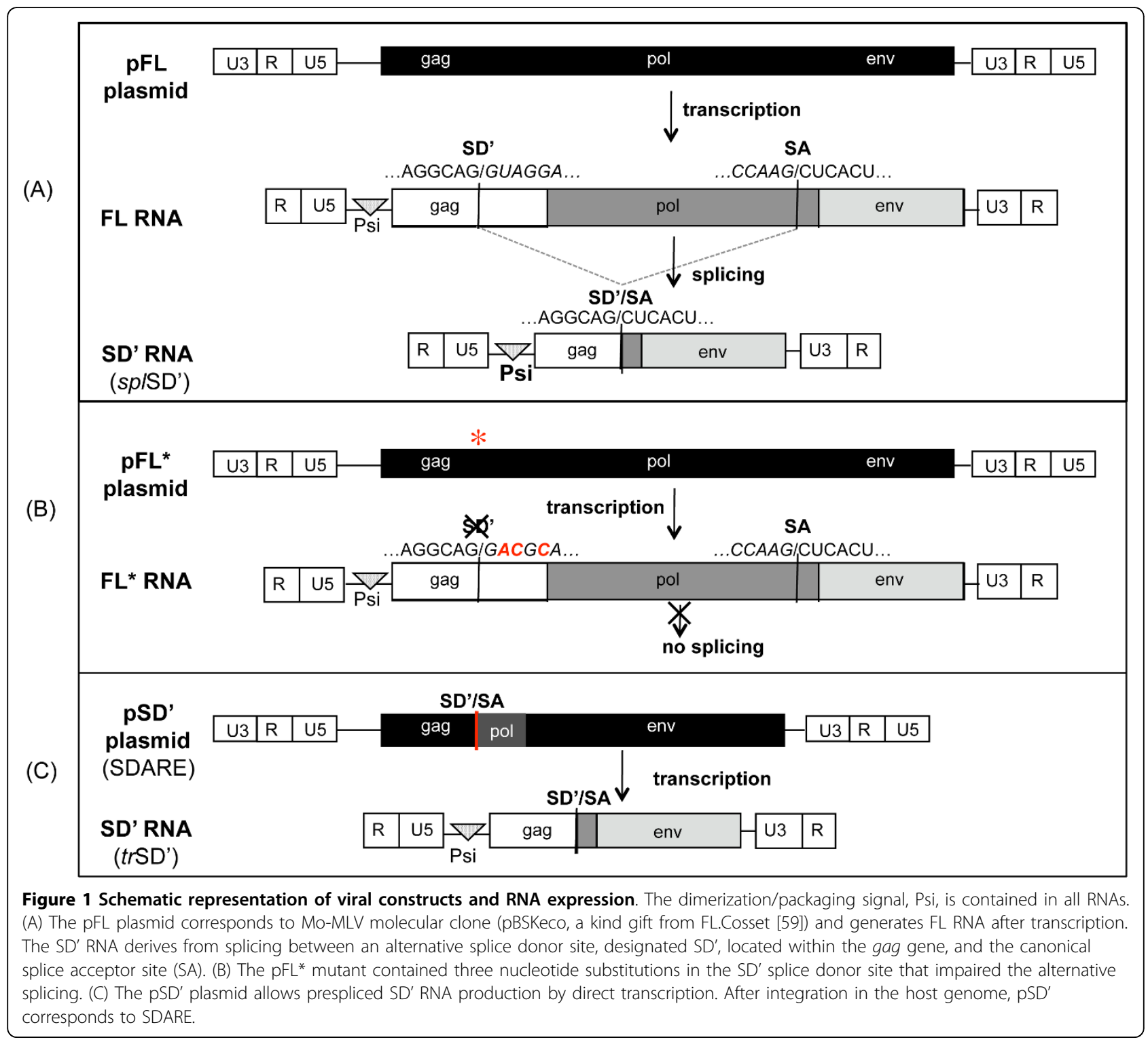


MLV pathogenesis $[34,37,38]$. Here, we took advantage of the propensity of the SD' RNA to form FLSD' heterodimers to study the impact of SD' transcription or splicing on MLV RNA dimerization.

\section{Transcription and dimerization}

It has been reported that co-packaging of two MLV RNAs was dependent on the distance between their transcription sites $[27,28]$. These studies were based on the previous finding that stable co-transfection of two different plasmid DNAs lead to their integration as concatamers whereas a two-step stable transfection lead to two independent integration events [39-43]. These two transfection methods were validated for MLV-based vectors carrying different selectable markers. When two different viral RNAs were produced from tandem integrations by the one-step method, local and overlapping accumulation of both RNA transcripts were observed. In contrast, there was no co-localization of the RNAs generated by distinct transcription cassettes in the two-step approach $[27,28]$.

Here, we investigated whether the link between preferential co-packaging of two MLV RNAs and the proximity of their transcription sites was due to RNA dimerization [30]. To explore this possibility, we used the characteristic of MLV to produce two different proviruses, MLV and SDARE, which generate FL and SD' RNA transcripts, respectively [31]. To prevent the production of SD' RNA by splicing of the FL RNA, we used a mutant MLV carrying an inactive SD' site (pFL*) (Figure 1B). This mutation did not activate cryptic splicing sites and it slightly affected the MLV replication in vitro and in vivo (also called M1 or MSD1 in $[32,34,35]$ ). We used the same genetic approaches as previously validated, in which spatial positions of MLV proviral transcription sites are modulated by one versus two -step stable transfections [27,28,39-43]. Stably transfected 293-cell lines were established in which the FL and SD' (trSD') RNAs were transcribed from $\mathrm{pFL}^{*}$ and SDARE molecular clone (pSD'), respectively [31] (Figure 1C). The $\mathrm{pFL}^{*}$ and $\mathrm{pSD}$ ' plasmids were transfected together or sequentially to generate integrations in tandem or in distant loci, respectively (Figure $2 \mathrm{AB}$ ). After selection, resistant colonies were pooled and RNA extracted from total cell extracts. Viral FL and SD' RNAs as well as the GAPDH mRNA were quantified by RT-QPCR as previously described [36]. The results indicate that the trSD' and FL RNAs are equally transcribed in both contexts (Figure 2AB). The quantification of intracellular RNA dimers has long been an unresolved technical problem. Therefore, we measured the heterodimers in released virions, by using RNA Capture Assay (RCA), a tool designated to examine heterodimerization between two distinct RNAs [29]. All RCA steps were previously described for FLSD' heterodimerization analysis and were followed meticulously [36]. The major steps are briefly outlined in Figure 3. The FL RNA is used as a bait that was retained on the magnetic beads via a complementary biotinylated oligonucleotide. The SD' RNA was only captured via its association with FL RNA. Thus, SD' RNA presence in the elution can be used as a measure of heterodimerization. As described previously, the occurrence of heterodimerization was controlled by heat-denaturating the RNA samples before capture, in order to dissociate dimers. SD' RNA was no longer captured in the heat-treated samples [36]. The copy numbers of the FL and SD' RNAs were measured in the virion input and the elution fractions by specific RTQPCR as previously described [31,36,44], and the SD' proportions in input and in elution samples are reported in Table 1. The elution/input ratios calculated for SD' reflect to some extent the heterodimerization efficiencies. Results from the two transfection procedures revealed that heterodimerization was $\sim 30$-times more efficient for proviruses integrated simultaneously, and presumably in tandem, than for proviruses integrated independently and likely in different loci.

To deduce the distribution of FLSD' heterodimers predicted for random RNA dimerization, we used the Hardy-Weinberg equation, as previously described for MLV RNA dimerization [29]. Predicted heterodimer proportions were compared to those determined experimentally (Table 2, column (3)). The two stably-transfected cell lines strongly differ in randomness of heterodimerization. For integrations in tandem, heterodimers formed at a frequency similar to that predicted from random RNA assortment. In contrast, for independent integrations, FL and SD' RNAs associated according to a non-random distribution, as previously reported $[29,30]$.

These findings imply that MLV RNA dimer-partner selection occurs co-transcriptionally or within a pool of transcripts near the proviral templates. Our results correlate with previous studies showing the preferential copackaging of MLV RNAs transcribed from the same chromosomal site $[27,28]$. Our finding indicates that RNA dimerization might be responsible for this preference.

\section{Splicing and dimerization}

RNA splicing is spatially and functionally linked to transcription [45]. Therefore, the possibility of a correlation between splicing and dimerization, as already noted above for transcription and dimerization, was investigated. To test this new hypothesis, we determined the FLSD' heterodimerization efficiency with a SD' RNA issued exclusively from splicing (splSD'). Cells were stably transfected with wild-type replication-competent 

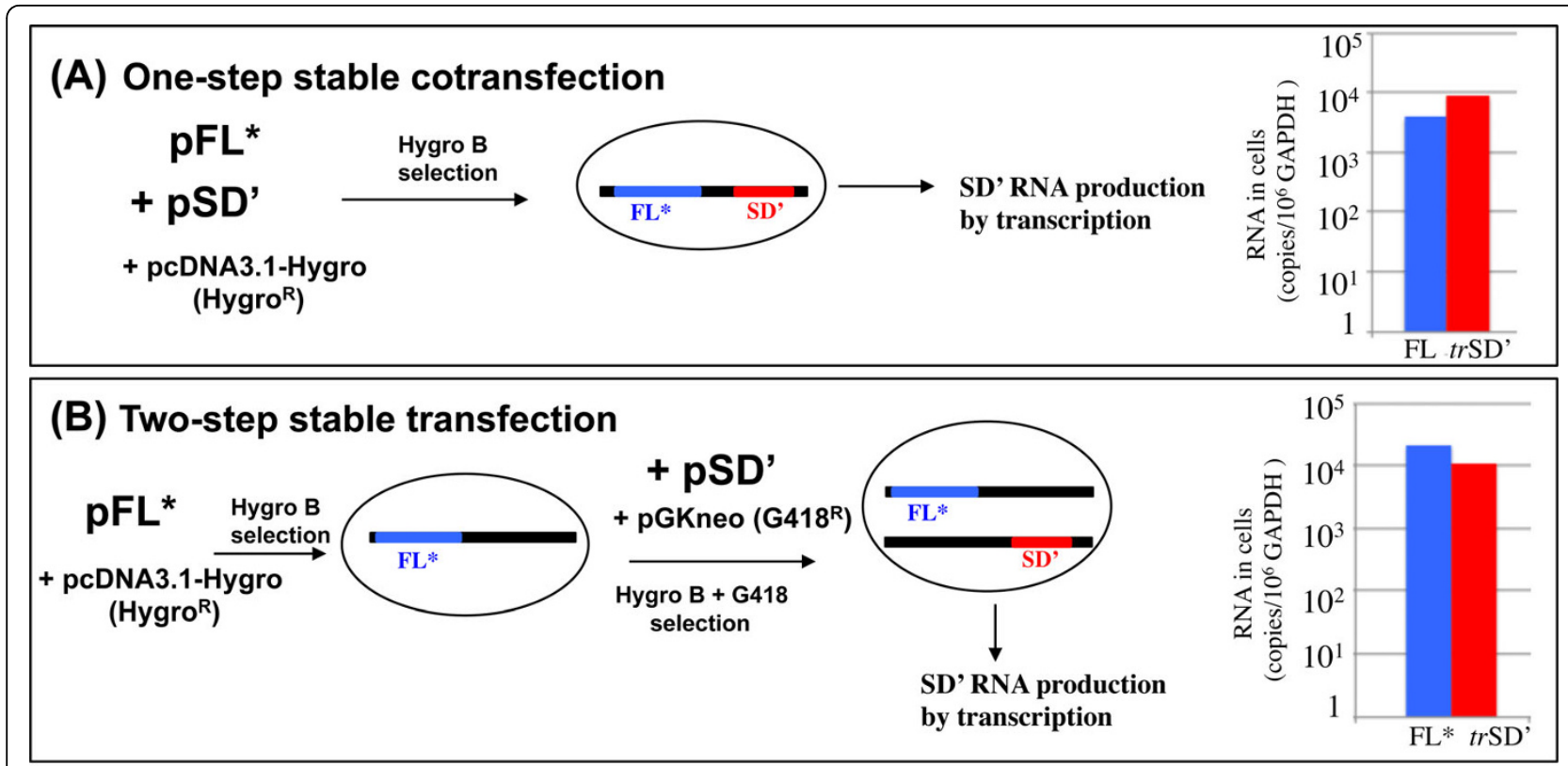

\section{(C) Stable transfection}


Figure 2 Experimental strategy to study FLSD' heterodimerization in different cellular contexts. Thick lines correspond to viral proviruses with genomic and SD' templates in blue and red, respectively. (A) One-step stable co-transfection of $\mathrm{pFL}^{*}$ and $\mathrm{pSD}^{\prime}$ allows concomitant integration of the two proviruses. Presumably, the transcription sites of the SD' and the FL RNAs are in close proximity on the chromosome. (B) Two-step stable transfections of pFL* and pSD' lead to sequential and independent integration events. SD' RNA is synthesized by transcription of a SDARE integrated in a site distant to that of FL provirus. (C) Stable transfection was performed with the replication-competent MLV molecular clone. SD' RNA is produced by splicing of the FL RNA. For each procedure, levels of the FL and SD' RNAs in stably transfected cells were determined by RT-QPCR. RNA copy numbers (cps) normalized to $10^{6} \mathrm{cPs}$ GAPDH mRNA are given in the graphs.

MLV clone (here named $\mathrm{pFL}$ ) and pcDNA-hygro plasmid (Figure 1A). After transcription, the FL RNA undergoes splicing to generate the SD' RNA. As expected, splSD' RNA was less abundant than FL RNA in these cells $\left(s p l \mathrm{SD}^{\prime} / \mathrm{FL}\right.$ ratio is 1:50) (Figure $2 \mathrm{C}$ ). Nevertheless, virion content analysis by RCA showed that spliced splSD' RNA represented $0.1 \%$ of total elution leading to a heterodimerization efficiency of $36-42 \%$. Interestingly, this efficiency was similar to that measured for coexpressed trSD' and FL RNAs when their respective DNAs were cotransfected (Table. 1). Likewise, the splSD' and FL RNAs segregated at a frequency close to that predicted from a random distribution (Table. 2).

Such a link between splicing and dimerization provides possible clues to the packaging process of spliced viral RNAs. Although the genomic RNA is preferentially packaged, the subgenomic RNAs are also specifically packaged into infectious HIV and MLV particles, although to a lower extent [31,46-48]. Such co-packaging of spliced and FL RNAs possibly involves heterodimerization. This model is supported by the ability of the MLV SD' spliced RNA to heterodimerize with the genomic RNA [36]. Note that HIV spliced RNAs were also able to dimerize in vitro [49,50]. It is still not clear how splicing contributes to dimerization. Dimerization might precede and somehow modulate splicing so that only one FL RNA molecule is spliced within FLFL homodimers, leading to asymmetrical dimers (FLSD'). Alternatively, the FL and SD' RNAs could associate during or soon after the splicing process is finished. This latter model correlates with our findings that splicing and cotranscription conferred similar heterodimerization 




Table 1 Comparative study of heterodimerization frequencies for SD' RNA produced in the different cellular contexts.

\begin{tabular}{|c|c|c|c|c|c|c|c|c|}
\hline \multirow[t]{5}{*}{ Experiment 1} & \multirow[t]{2}{*}{ SD' ORIGIN } & \multicolumn{3}{|c|}{ VIRION INPUT ${ }^{(1)}$} & \multicolumn{3}{|c|}{ ELUTION $^{(2)}$} & \multirow[t]{2}{*}{$\% \mathrm{SD}^{\prime}{ }^{(4)}$ (elution/input) $\times 100$} \\
\hline & & FL (cps) & $\mathrm{SD}^{\prime}$ (cps) & \%SD' & FL (cps) & SD' (cps) $^{\prime}$ & $\% \mathrm{SD}^{\prime}{ }^{(3)}$ & \\
\hline & transcription in same locus as FL & 4.13E+06 & $4.24 \mathrm{E}+06$ & 50.63 & $2.47 \mathrm{E}+05$ & $4.83 \mathrm{E}+04$ & 16.35 & 32.3 \\
\hline & transcription in distinct locus to $\mathrm{FL}$ & $1.28 \mathrm{E}+08$ & $3.60 \mathrm{E}+07$ & 21.93 & $7.73 \mathrm{E}+06$ & $1.60 \mathrm{E}+04$ & 0.207 & 0.9 \\
\hline & splicing & $9.80 \mathrm{E}+07$ & $2.37 \mathrm{E}+05$ & 0.24 & $6.34 \mathrm{E}+06$ & $5.54 \mathrm{E}+03$ & 0.087 & 36.1 \\
\hline \multirow[t]{5}{*}{ Experiment 2} & SD' ORIGIN & \multicolumn{3}{|c|}{ VIRION INPUT ${ }^{(1)}$} & \multicolumn{3}{|c|}{ ELUTION ${ }^{(2)}$} & $\% \mathrm{SD}^{\prime}{ }^{(4)}$ (elution/input) $\times 100$ \\
\hline & & FL (cps) & SD' (cps) & \%SD' & FL (cps) & SD' (cps) $^{\prime}$ & $\% \mathrm{SD}^{\prime}(3)$ & \\
\hline & transcription in same locus as FL & $1.66 \mathrm{E}+07$ & $1.47 \mathrm{E}+07$ & 46.93 & $1.28 \mathrm{E}+06$ & $2.54 \mathrm{E}+05$ & 16.54 & 35.3 \\
\hline & transcription in distinct locus to FL & $2.86 \mathrm{E}+08$ & $3.44 \mathrm{E}+07$ & 10.74 & $9.81 E+06$ & $1.86 \mathrm{E}+04$ & 0.19 & 1.8 \\
\hline & splicing & $8.57 \mathrm{E}+07$ & $2.93 \mathrm{E}+05$ & 0.34 & $6.21 E+06$ & $8.97 \mathrm{E}+03$ & 0.144 & 42.4 \\
\hline
\end{tabular}

Two independent RCA experiments were conducted from each HEK-293 cell line stably established as described in Fig.2. (1) Proportion of FL and SD' RNAs in virion input. The copies of FL and SD' RNAs determined in total virion samples before the RCA are indicated as well as the corresponding percent of SD' RNA in input. (2) The copies of captured FL and SD' RNAs quantified in total elution samples are indicated. (3) The \% SD' in the elution was calculated as (SD'/(FL+SD')) $\times$ 100. (4) The FL RNA was the oligonucleotide-bound RNA, which should be retained by the beads and present in the elution. The SD' RNA was retained on the beads via its association with FL RNA and represents the heterodimer population. Based on the proportion of SD' in input, the proportion of SD' contributing to heterodimerization was calculated as the ratio of elution/input for $\mathrm{SD}^{\prime}$ which corresponds to some extent to the heterodimerization efficiency. 
Table 2 Comparison between the predicted and the measured heterodimerization efficiencies.

\begin{tabular}{|c|c|c|c|c|c|c|}
\hline \multirow[t]{5}{*}{$\begin{array}{l}\text { Experiment } \\
\quad 1\end{array}$} & \multirow[t]{2}{*}{ SD' ORIGIN } & \multicolumn{3}{|c|}{$\begin{array}{l}\text { Predicted distribution of } \\
\text { homo- and hetero- dimers } \\
\text { (1) }\end{array}$} & \multirow{2}{*}{$\begin{array}{l}\text { \% of heterodimers captured in } \\
\text { RCA (2) } \\
\text { FLSD' (\%) }\end{array}$} & \multirow{2}{*}{$\begin{array}{c}\begin{array}{c}\text { randomness of } \\
\text { heterodimerization }\end{array} \\
\text { prediction/experiment }\end{array}$} \\
\hline & & $\begin{array}{c}\text { FLFL } \\
(\%)\end{array}$ & $\begin{array}{l}\text { SD'SD' }^{\prime} \\
(\%)\end{array}$ & $\begin{array}{l}\text { FLSD' }^{\prime} \\
(\%)\end{array}$ & & \\
\hline & $\begin{array}{c}\text { transcription in same locus as } \\
\mathrm{FL}\end{array}$ & 24.4 & 25.6 & 50 & 32.7 & 1.53 \\
\hline & $\begin{array}{c}\text { transcription in distinct locus } \\
\text { to FL }\end{array}$ & 60.9 & 4.8 & 34.2 & 0.41 & 83.4 \\
\hline & splicing & 99.5 & 0.0006 & 0.5 & 0.17 & 2.9 \\
\hline \multirow[t]{5}{*}{$\begin{array}{l}\text { Experiment } \\
\quad 2\end{array}$} & SD' ORIGIN & \multicolumn{3}{|c|}{$\begin{array}{l}\text { Predicted distribution of } \\
\text { homo- and hetero- dimers } \\
\text { (1) }\end{array}$} & $\begin{array}{l}\% \text { of heterodimers captured in } \\
\text { RCA (2) }\end{array}$ & $\begin{array}{c}\text { randomness of } \\
\text { heterodimerization }\end{array}$ \\
\hline & & $\begin{array}{l}\text { FLFL } \\
(\%)\end{array}$ & $\begin{array}{l}\text { SD'SD' }^{\prime} \\
(\%)\end{array}$ & $\begin{array}{l}\text { FLSD' }^{\prime} \\
(\%)\end{array}$ & FLSD' (\%) & prediction/experiment \\
\hline & $\begin{array}{c}\text { transcription in same locus as } \\
\mathrm{FL}\end{array}$ & 28.2 & 22 & 50 & 33.1 & 1.51 \\
\hline & $\begin{array}{l}\text { transcription in distinct locus } \\
\text { to FL }\end{array}$ & 79.7 & 1.2 & 19.2 & 0.38 & 50.53 \\
\hline & splicing & 99.3 & 0.001 & 0.7 & 0.29 & 2.41 \\
\hline
\end{tabular}

(1) To deduce the distribution of FLSD' RNA heterodimers predicted for random RNA dimerization, we used the Hardy-Weinberg equation $\left(A^{2}+2 A B+B^{2}=1\right)$, as previously described in details by Flynn et al. [29]. In this equation, $A^{2}$ and $B^{2}$ represent the percentage of FLFL and SD'SD' homodimers, respectively, and 2AB the FLSD' heterodimer population. Based on proportions of FL and SD' RNAs experimentally determined in virion input (Table 1), this equation allows the calculation of predicted percentages of $\mathrm{AA}(\mathrm{FLFL})$ and $\mathrm{BB}\left(\mathrm{SD}^{\prime} \mathrm{SD}^{\prime}\right)$ homodimers in the viral population, and $\mathrm{AB}$ heterodimers (FLSD') represent the remaining percentage of the population. (2) The proportion of heterodimer experimentally determined by RCA was calculated from \%SD' given in Table 1 as ( $\left.2 \times \% \mathrm{SD}^{\prime}\right)$. ( 3 ) To determine the randomness of heterodimerization in the different HEK 293-derived cell-lines, the \%FLSD' determined by the capture experiments were compared to that obtained by the prediction (predicted/measured).

efficiencies, implying the recruitment of a common mechanism for the two pathways.

Altogether our results showed that MLV RNAs preferentially dimerize when they undergo splicing or co-transcription. In contrast, the distance between transcription sites could hinder RNA dimerization. At least two nonexclusive hypotheses could explain these results. Host factors could play a role in dimerization [20,51]. For instance, transcription or splicing factors may confer a higher accessibility to the 5' end of the RNA including the dimer linkage structure (DLS) and thereby allows for better recognition of the DLS by the RNA partner and/or by Gag. Also, a direct role for an unidentified host candidate cannot be excluded. Similarly, nascent RNAs that are undergoing synthesis might adopt a more favorable conformation for dimerization compared to complete transcripts. In support of this model, dimerization occurred more efficiently for large synthetic MLV or HIV RNAs during in vitro transcription than postsynthesis $[30,36,49]$. Alternatively, co-transcription and splicing could enhance dimerization by providing high local RNA concentration in a subnuclear domain that facilitates RNA-RNA interactions. This mechanism is supported by previous studies showing that MLV RNA dimerization is dependent on RNA concentration in vitro $[6,52]$. Furthermore, it correlates with the nuclear accumulation of the viral FL RNA (75\%) observed in MLV-producing cells [44].

Our results suggest that viral RNAs dimerize in the nucleus and presumably traffic out of the nucleus as dimers. Importantly, the MLV packaging signal (Psi) which overlaps the DLS, also contributes to nuclear export of the FL RNA $[44,53]$. Therefore, dimerization may impact on the RNA export pathway and determine the cytoplasmic fate of the RNA [54]. Dimers would be routed to virus assembly sites and packaged to serve as the viral genome, while monomers would be processed by the translation machinery to encode viral proteins. This would explain the occurrence of two functionally distinct pools of MLV FL RNA [55,56] and is supported by the nuclear localization of MLV Gag protein [24]. In agreement with this attractive model that we are testing in our laboratory, two articles were published upon completion of our manuscript, concluding that transient nuclear trafficking of Gag is required for RNA encapsidation in RSV or lentiviral particles $[57,58]$.

\section{Acknowledgements}

We thank laboratory members past and present, including Laurent Houzet, Fatima Smagulova, and Zakia Morichaud for help and advice throughout this work. Special thanks to Laurent Houzet for constant interest and helpful comments on the manuscript. We thank Drs. R. Kiernan and C. JacquéO'Reilly for the critical reading of the manuscript. This work was supported 
by $\mathrm{ACl} / \mathrm{ANR}$ grant and by CNRS. SM was supported by a fellowship from ACI/ANR.

\section{Authors' contributions}

SM and MM conceived the study and analyzed the data. SM performed the laboratory work. MM wrote the manuscript. The authors read and approved the final manuscript.

Received: 9 June 2010 Accepted: 5 August 2010

Published: 5 August 2010

\section{References}

1. Temin HM: Sex and recombination in retroviruses. Trends Genet 1991, 7:71-74.

2. Butsch M, Boris-Lawrie K: Destiny of unspliced retroviral RNA: ribosome and/or virion? J Virol 2002, 76:3089-3094.

3. Tounekti N, Mougel M, Roy C, Marquet R, Darlix JL, Paoletti J, Ehresmann B, Ehresmann C: Effect of dimerization on the conformation of the encapsidation Psi domain of Moloney murine leukemia virus RNA. J Mol Biol 1992, 223:205-220.

4. Miyazaki Y, Garcia EL, King SR, Iyalla K, Loeliger K, Starck P, Syed S, Telesnitsky A, Summers MF: An RNA structural switch regulates diploid genome packaging by Moloney murine leukemia virus. J Mol Biol 396:141-152.

5. D'Souza V, Summers MF: Structural basis for packaging the dimeric genome of Moloney murine leukaemia virus. Nature 2004, 431:586-590.

6. De Tapia M, Metzler V, Mougel M, Ehresmann B, Ehresmann C: Dimerization of MoMuLV genomic RNA: redefinition of the role of the palindromic stem-loop $\mathrm{H} 1$ (278-303) and new roles for stem-loops $\mathrm{H} 2$ (310- 352) and H3 (355-374). Biochemistry 1998, 37:6077-6085.

7. Badorrek CS, Gherghe CM, Weeks KM: Structure of an RNA switch that enforces stringent retroviral genomic RNA dimerization. Proc Natl Acad Sci USA 2006, 103:13640-13645

8. Ooms M, Huthoff $H$, Russell $R$, Liang $C$, Berkhout B: A riboswitch regulates RNA dimerization and packaging in human immunodeficiency virus type 1 virions. J Virol 2004, 78:10814-10819.

9. Mikkelsen JG, Lund AH, Duch M, Pedersen FS: Mutations of the kissingloop dimerization sequence influence the site specificity of murine leukemia virus recombination in vivo. J Virol 2000, 74:600-610.

10. Housset $V$, De Rocquigny $H$, Roques BP, Darlix JL: Basic amino acids flanking the zinc finger of Moloney murine leukemia virus nucleocapsid protein NCp10 are critical for virus infectivity. J Virol 1993, 67:2537-2545.

11. Paoletti J, Mougel M, Tounekti N, Girard PM, Ehresmann C, Ehresmann B: Spontaneous dimerization of retroviral MoMuLV RNA. Biochimie 1993, 75:681-686.

12. Hansen $M$, Jelinek $L$, Jones RS, Stegeman-Olsen J, Barklis E: Assembly and composition of intracellular particles formed by Moloney murine leukemia virus. J Virol 1993, 67:5163-5174.

13. Rasmussen SV, Mikkelsen JG, Pedersen FS: Modulation of homo- and heterodimerization of Harvey sarcoma virus RNA by GACG tetraloops and point mutations in palindromic sequences. J Mol Biol 2002 323:613-628.

14. D'Souza V, Melamed J, Habib D, Pullen K, Wallace K, Summers MF: Identification of a high affinity nucleocapsid protein binding element within the Moloney murine leukemia virus Psi-RNA packaging signal: implications for genome recognition. J Mol Biol 2001, 314:217-232.

15. Torrent C, Bordet T, Darlix JL: Analytical study of rat retrotransposon VL30 RNA dimerization in vitro and packaging in murine leukemia virus. $J \mathrm{Mol}$ Biol 1994, 240:434-444.

16. Mougel $M$, Zhang $Y$, Barklis E: Cis-active structural motifs involved in specific encapsidation of Moloney Murine Leukemia Virus RNA. J Virol 1996, 70:5043-5050.

17. Hibbert CS, Mirro J, Rein A: mRNA molecules containing murine leukemia virus packaging signals are encapsidated as dimers. J Virol 2004, 78:10927-10938.

18. Fisher J, Goff SP: Mutational analysis of stem-loops in the RNA packaging signal of the Moloney murine leukemia virus. Virology 1998, 244:133-145.

19. Russell RS, Liang C, Wainberg MA: Is HIV-1 RNA dimerization a prerequisite for packaging? Yes, no, probably? Retrovirology 2004, 1:23.

20. Paillart JC, Shehu-Xhilaga M, Marquet R, Mak J: Dimerization of retroviral RNA genomes: an inseparable pair. Nat Rev Microbiol 2004, 2:461-472.
21. D'Souza V, Summers MF: How retroviruses select their genomes. Nat Rev Microbiol 2005, 3:643-655.

22. Chen J, Nikolaitchik O, Singh J, Wright A, Bencsics CE, Coffin JM, Ni N, Lockett S, Pathak VK, Hu WS: High efficiency of HIV-1 genomic RNA packaging and heterozygote formation revealed by single virion analysis. Proc Natl Acad Sci USA 2009, 106:13535-13540.

23. Jouvenet N, Simon SM, Bieniasz PD: Imaging the interaction of HIVgenomes and Gag during assembly of individual viral particles. Proc Natl Acad Sci USA 2009, 106:19114-19119.

24. Nash MA, Meyer MK, Decker GL, Arlinghaus RB: A subset of Pr65gag is nucleus associated in murine leukemia virus-infected cells. J Virol 1993 67:1350-1356.

25. Dupont S, Sharova N, DeHoratius C, Virbasius CM, Zhu X, Bukrinskaya AG, Stevenson M, Green MR: A novel nuclear export activity in HIV-1 matrix protein required for viral replication. Nature 1999, 402:681-685.

26. Garbitt-Hirst R, Kenney SP, Parent LJ: Genetic evidence for a connection between Rous sarcoma virus gag nuclear trafficking and genomic RNA packaging. J Virol 2009, 83:6790-6797.

27. Kharytonchyk SA, Kireyeva Al, Osipovich AB, Fomin IK: Evidence for preferential copackaging of Moloney murine leukemia virus genomic RNAs transcribed in the same chromosomal site. Retrovirology 2005, 2:3.

28. Rasmussen SV, Pedersen FS: Co-localization of gammaretroviral RNAs at their transcription site favours co-packaging. J Gen Virol 2006, 87:2279-2289.

29. Flynn JA, An W, King SR, Telesnitsky A: Nonrandom dimerization of murine leukemia virus genomic RNAs. J Virol 2004, 78:12129-12139.

30. Flynn JA, Telesnitsky A: Two distinct Moloney murine leukemia virus RNAs produced from a single locus dimerize at random. Virology 2006, 344:391-400.

31. Houzet $L$, Battini $J$, Bernard $E$, Thibert $V$, Mougel M: A new retroelement constituted by a natural alternatively spliced RNA of murine replicationcompetent retroviruses. EMBO J 2003, 22:4866-4875.

32. Dejardin J, Bompard-Marechal G, Audit M, Hope TJ, Sitbon M, Mougel M: A Novel Subgenomic Murine Leukemia Virus RNA Transcript Results from Alternative Splicing. J Virol 2000, 74:3709-3714.

33. Mukhopadhyaya R, Wolff L: New sites of integration associated with murine promonocytic leukemias and evidence for alternate modes of $c$ myb activation. J Virol 1992, 66:6035-6044

34. Ramirez JM, Houzet $L$, Koller R, Bies J, Wolff $L$, Mougel M: Activation of cmyb by $5^{\prime}$ retrovirus promoter insertion in myeloid neoplasms is dependent upon an intact alternative splice donor site (SD') in gag. Virology 2004, 330:398-407

35. Audit M, Dejardin J, Hohl B, Sidobre C, Hope TJ, Mougel M, Sitbon M: Introduction of a cis-acting mutation in the capsid-coding gene of moloney murine leukemia virus extends its leukemogenic properties. $J$ Virol 1999, 73:10472-10479.

36. Maurel S, Houzet L, Garcia EL, Telesnitsky A, Mougel M: Characterization of a natural heterodimer between MLV genomic RNA and the SD retroelement generated by alternative splicing. RNA 2007, 13:2266-2276.

37. Muriaux D, Rein A: Encapsidation and transduction of cellular genes by retroviruses. Front Biosci 2003, 8:D135-142.

38. Moore MD, Fu W, Nikolaitchik O, Chen J, Ptak RG, Hu WS: Dimer initiation signal of human immunodeficiency virus type 1 : its role in partner selection during RNA copackaging and its effects on recombination. $J$ Virol 2007, 81:4002-4011.

39. Chen C, Chasin LA: Cointegration of DNA molecules introduced into mammalian cells by electroporation. Somat Cell Mol Genet 1998, 24:249-256.

40. Perucho M, Hanahan D, Wigler M: Genetic and physical linkage of exogenous sequences in transformed cells. Cell 1980, 22:309-317.

41. Goff SP, Tabin CJ, Wang JY, Weinberg R, Baltimore D: Transfection of fibroblasts by cloned Abelson murine leukemia virus DNA and recovery of transmissible virus by recombination with helper virus. J Virol 1982, 41:271-285.

42. Goldfarb MP, Weinberg RA: Structure of the provirus within NIH 3 T3 cells transfected with Harvey sarcoma virus DNA. J Virol 1981, 38:125-135.

43. Wang ML, Lee AS: Polymerization of vector DNA after transfection into hamster fibroblast cells. Biochem Biophys Res Commun 1983, 110:593-601.

44. Smagulova F, Maurel S, Morichaud Z, Devaux C, Mougel M, Houzet L: The highly structured encapsidation signal of MuLV RNA is involved in the nuclear export of its unspliced RNA. J Mol Biol 2005, 354:1118-1128. 
45. Szentirmay MN, Sawadogo M: Spatial organization of RNA polymerase II transcription in the nucleus. Nucleic Acids Res 2000, 28:2019-2025.

46. Houzet L, Paillart JC, Smagulova F, Maurel S, Morichaud Z, Marquet R, Mougel M: HIV controls the selective packaging of genomic, spliced viral and cellular RNAs into virions through different mechanisms. Nucleic Acids Res 2007, 35:2695-2704.

47. Houzet L, Morichaud Z, Mougel M: Fully-spliced HIV-1 RNAs are reverse transcribed with similar efficiencies as the genomic RNA in virions and cells, but more efficiently in AZT-treated cells. Retrovirology 2007, 4:30

48. Liang C, Hu J, Russell RS, Kameoka M, Wainberg MA: Spliced human immunodeficiency virus type 1 RNA is reverse transcribed into CDNA within infected cells. AIDS Res Hum Retroviruses 2004, 20:203-211.

49. Sinck L, Richer D, Howard J, Alexander M, Purcell DF, Marquet R, Paillart JC: In vitro dimerization of human immunodeficiency virus type 1 (HIV-1) spliced RNAs. RNA 2007, 13:2141-2150.

50. Lanchy JM, Szafran QN, Lodmell JS: Splicing affects presentation of RNA dimerization signals in HIV-2 in vitro. Nucleic Acids Res 2004, 32:4585-4595.

51. Moore MD, Hu WS: HIV-1 RNA dimerization: It takes two to tango. AIDS Rev 2009, 11:91-102.

52. Oroudjev EM, Kang PC, Kohlstaedt LA: An additional dimer linkage structure in Moloney murine leukemia virus RNA. J Mol Biol 1999, 291:603-613.

53. Basyuk E, Boulon S, Skou Pedersen F, Bertrand E, Vestergaard Rasmussen S: The packaging signal of MLV is an integrated module that mediates intracellular transport of genomic RNAs. J Mol Biol 2005, 354:330-339.

54. Stutz F, Izaurralde $E$ : The interplay of nuclear mRNP assembly, mRNA surveillance and export. Trends Cell Biol 2003, 13:319-327.

55. Dorman N, Lever A: Comparison of viral genomic RNA sorting mechanisms in human immunodeficiency virus type 1 (HIV-1), HIV-2, and Moloney murine leukemia virus. J Virol 2000, 74:11413-11417.

56. Levin JG, Rosenak MJ: Synthesis of murine leukemia virus proteins associated with virions assembled in actinomycin D-treated cells: evidence for persistence of viral messenger RNA. Proc Natl Acad Sci USA 1976, 73:1154-1158.

57. Gudleski N, Flanagan JM, Ryan EP, Bewley MC, Parent LJ: Directionality of nucleocytoplasmic transport of the retroviral gag protein depends on sequential binding of karyopherins and viral RNA. Proc Natl Acad Sci USA 2010, 107:9358-9363.

58. Kemler I, Meehan A, Poeschla EM: Live-cell coimaging of the genomic RNAs and Gag proteins of two lentiviruses. J Virol 2010, 84:6352-6366.

59. Shinnick TM, Lerner RA, Sutcliffe JG: Nucleotide sequence of Moloney murine leukaemia virus. Nature 1981, 293:543-548.

doi:10.1186/1742-4690-7-64

Cite this article as: Maurel and Mougel: Murine leukemia virus RNA dimerization is coupled to transcription and splicing processes. Retrovirology 2010 7:64.

\section{Submit your next manuscript to BioMed Central and take full advantage of:}

- Convenient online submission

- Thorough peer review

- No space constraints or color figure charges

- Immediate publication on acceptance

- Inclusion in PubMed, CAS, Scopus and Google Scholar

- Research which is freely available for redistribution

Submit your manuscript at www.biomedcentral.com/submit
Ciomed Central 